\title{
PELESTARIAN KAWASAN PECINAN KEMBANG JEPUN KOTA SURABAYA BERDASARKAN PERSEPSI MASYARAKAT
}

\author{
Kartika Eka Sari $^{1)}$, Antariksa $^{2)}$, dan Eddi Basuki Kurniawan ${ }^{3)}$ \\ ${ }^{1,2,3)}$ Jurusan Perencanaan Wilayah dan Kota, Fakultas Teknik, Universitas Brawijaya, Malang \\ Email:kartikaeka@ub.ac.id; antariksa@ub.ac.id; eddibasuki@ub.ac.id
}

\begin{abstract}
ABSTRAK
Tujuan penelitian adalah mengidentifikasi karakter fisik, sosial, ekonomi dan budaya kawasan Kembang Jepun, menganalisis potensi masalah terkait pelestarian kawasan Kembang Jepun dan menentukan strategi pelestarian kawasan Kembang Jepun. Persepsi masyarakat digunakan untuk menganalisis bobot nilai-nilai makna kultural kawasan Kembang Jepun, terutama makna kultural umur, estetika, kelangkaan, keaslian, memperkuat kawasan dan citra kawasan. Berdasarkan metode IPA (Importance Performance Analysis), nilai-nilai makna kultural yang dijadikan prioritas utama (bobot 3) dalam penentuan strategi pelestarian bangunan di kawasan Kembang Jepun adalah makna kultural memperkuat kawasan (fungsi bangunan dipertahankan seperti aslinya), makna kultural citra kawasan (ciri bangunan diulang secara dominan pada bangunan lain, merupakan tengeran masyarakat dan fungsi sesuai dengan karakter kawasan Kembang Jepun). Makna kultural yang memiliki bobot 2 adalah Estetika, kelangkaan dan makna kultural yang memiliki bobot 1 adalah Umur dan Keaslian. Bobot makna kultural tersebut dikombinasikan dengan nilai makna kultural per-bangunan kuno dan didapatkan 11 bangunan kuno dengan strategi pelestarian Preservasi, 34 bangunan kuno dengan strategi pelestarian Konservasi, 27 bangunan kuno dengan strategi pelestarian Revitalisasi dan 17 bangunan kuno dengan strategi pelestarian Rehabilitasi.
\end{abstract}

Kata kunci: Pelestarian, Pecinan, Kembang Jepun.

\begin{abstract}
This research's objective are to identify physical, economic and culture characteristic of Kembang Jepun, analyze potention and issue related to Kembang Jepun's preservation and develop Kembang Jepun's preservation. Local communities's perception is use to analyze cultural meaning of Kembang Jepun, especially building's age, aesthetic, scarcity, originality, strengthen the cultural meaning and area's image. Based on IPA (Importance Performance Analysis) method, most priority for cultural meanings (scale 3) in determining building's preservation strategy in Kembang Jepun is to strengthen the cultural meaning (the original bulding's function in maintained), Area's image (building;s character is repeated dominantly, community's landmark and the function is suitable with Kembang Jepun's character). Cultural meaning that have scale 2 are aesthetic, scarcity and cultural meaning that have scale 1 are building's age and originality. Scales of cultural meanings (1 to 3) is combine with buildings's value and the result are: 11 ancient building for preservation's strategy, 34 ancient buildings for conservation's strategy, 27 ancient buildings for revitalitation's strategy and 17 ancient buildings for rehabilitation's strategy.
\end{abstract}

Keywords: Preservation, China town, Kembang Jepun.

\section{PENDAHULUAN}

Sebagai kota dengan sejarah panjang, Surabaya memiliki kawasan kota lama yang dikenal dengan nama Kota Bawah atau Beneden Stad yang berkembang sejak abad 18, lokasinya berada di sekitar kawasan Jl. Kembang Jepun, Ampel dan Jl. RajawaliVeteran. Sejarah panjang Kota Bawah dapat dilihat melalui keberadaan bangunan yang didirikan pada periode yang berbeda, mulai tahun 1870-an sampai dengan tahun 1900-an dengan langgam arsitektur yang beragam (Kwanda, 2004: 1). Salah satu ciri kota lama bentukan Pemerintah Kolonial Belanda adalah pembagian cluster berdasarkan etnis. Kota bawah atau beneden Stad terdiri dari Kawasan Eropa, Kawasan Tionghoa dan kawasan Arab (Handinoto, 1996: 91). Kawasan Eropa terletak di sebelah Barat
Jembatan Merah dan Kawasan Tionghoa, Melayu serta Arab terletak di sebelah timur Jembatan Merah (Handinoto 1996).

Menurut Faber dalam Handinoto (1996: 66), masyarakat Tionghoa sudah ada di Surabaya sejak tahun 1411 yang pada awalnya menempati daerah di Timur Kalimas yang disebut Chinese Camp. Masyarakat Tionghoa memegang peranan penting dalam kegiatan perdagangan Kota Surabaya. Pada masa Kolonial, masyarakat Tionghoa memiliki peran sebagai pedagang perantara antara orang pribumi sebagai penghasil produk-produk pertanian kemudian menjualnya pada pedagang-pedagang besar Eropa (Handinoto 1999: 24).

Seiring dengan perkembangan fungsi Kota Surabaya, khususnya di kawasan Kota Lama, maka peran Kembang Jepun sudah tidak sevital seperti pada 
masa Kolonial. Fenomen penurunan vitalitas Kawasan Kembang Jepun dapat dilihat dari beberapa aspek antara lain (Putra 2009 : 80-85), pudarnya karakteristik arsitektur Cina pada Kawasan Kembang Jepun, pudarnya tradisi kebudayaan Pecinan, hilangnya fungsi Ruko atau Rumah Toko dan tidak terawatnya lingkungan. Kawasan Kembang Jepun sebagai bagian dari Kota Bawah juga tidak terlepas dari kendala pelestarian dan turunnya kualitas lingkungan kawasan bersejarah (Putra 2008: 3). Salah satu penyebab turunnya kualitas lingkungan cagar budaya Kembang Jepun adalah kurangnya pengetahuan masyarakat tentang urban herritage dan kurangnya sosialisasi mengenai rencana pelestarian cagar budaya (Putra 2008: 137).

Upaya pelestarian bangunan dan kawasan bersejarah di Kota Surabaya mulai resmi dilakukan bersamaan dengan dikeluarkannya SK Walikota Nomor 188.45/251/251/402.1.04/1996 (Poerbantanoe 2001 : 44). Aplikasi pelestarian di Surabaya pada kenyataan mengalami beberapa kendala, terutama kurangnya informasi, motivasi dan kesadaran masyarakat tentang arti penting keberadaan kawasan Kembang Jepun sebagai cagar budaya (Bappeko 2003). Kurang dilibatkannya masyarakat dalam penyusunan rencana pelestarian kawasan cagar budaya menyebabkan kurang optmalnya informasi, motivasi dan kesadaran masyarakat terhadap kawasan cagar budaya. Oleh karena itu dalam penelitian ini melibatkan masyarakat untuk menjaring persepsi dan preferensi masyarakat yang beraktifitas di kawasan Kembang Jepun dalam menyusun rencana pelestarian kawasan pecinan Kembang Jepun.

\section{METODE PENELITIAN}

Jenis analisis yang digunakan antara lain analisis spasial dan analisis persepsi. Analisis spasial digunakan untuk menentukan karakter Kembang Jepun sebagai kawasan cagar budaya dari aspek spasial dengan menggunakan metode analisis struktur tata ruang, analisis place dan analisis figure fround. Analisi persepsi digunakan untuk mengevaluasi nilainilai makna kultural berdasarkan persepsi masyarakat dengan metode IPA (Importance Performance Analysis). Pemilihan metode IPA dikarenakan dengan Diagram Cartesius dalam metode IPA dapat diketahui tingkat kepentingan dan prioritas masing-masing item nilai makna kultural.

\section{HASIL DAN PEMBAHASAN}

\section{Sejarah Perkembangan}

Pada masa kolonial (tahun 1411) masyarakat Tionghoa sudah datang ke kota Surabaya dan hidup secara berkelompok di sebelah Timur Kalimas yang dibatasi oleh jalan Kembang Jepun (Utara), jalan Karet (Barat), jalan Coklat (Selatan) dan jalan Slompretan (Timur).

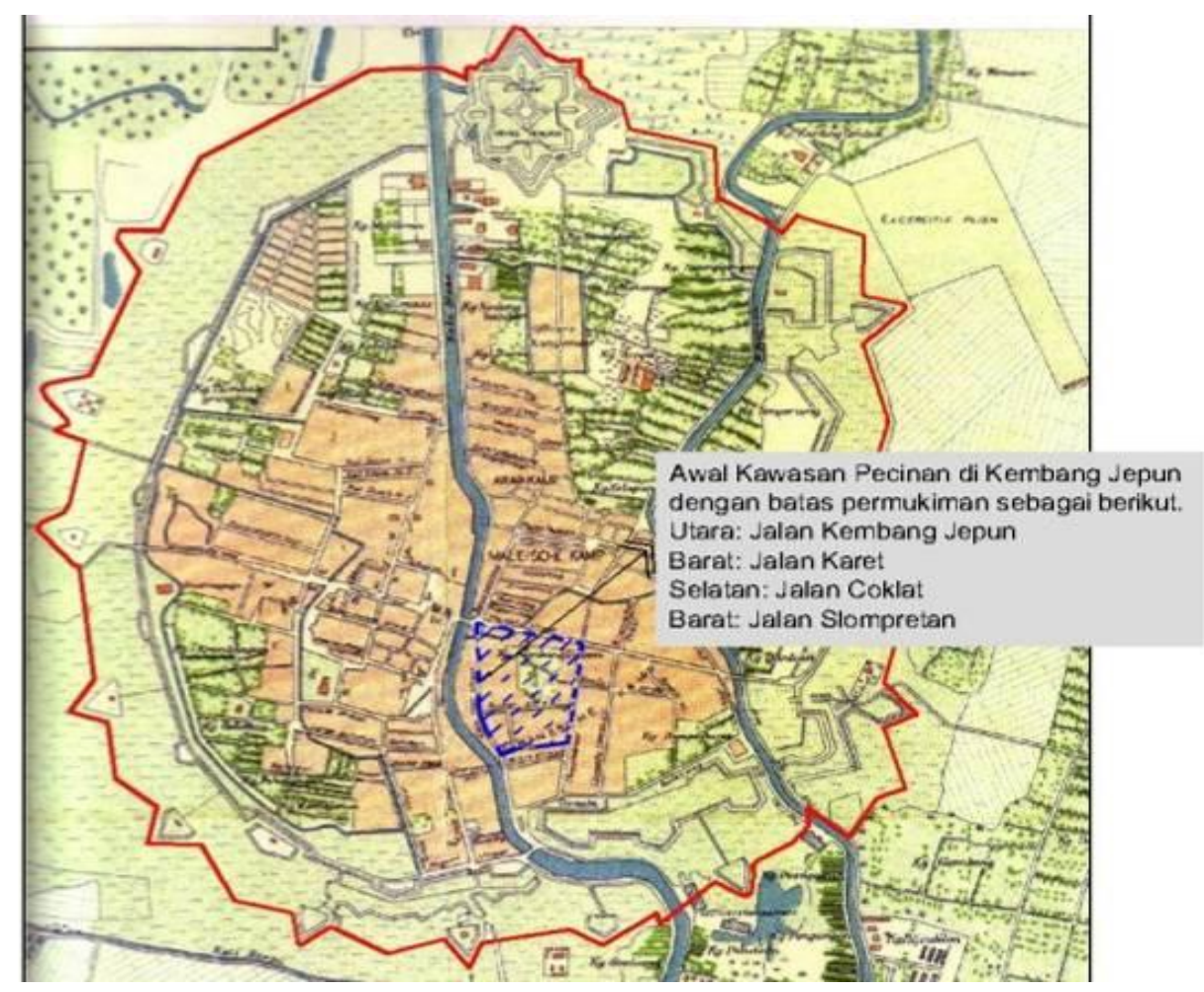

Gambar 1. Lokasi awal Pecinan Kembang Jepun 


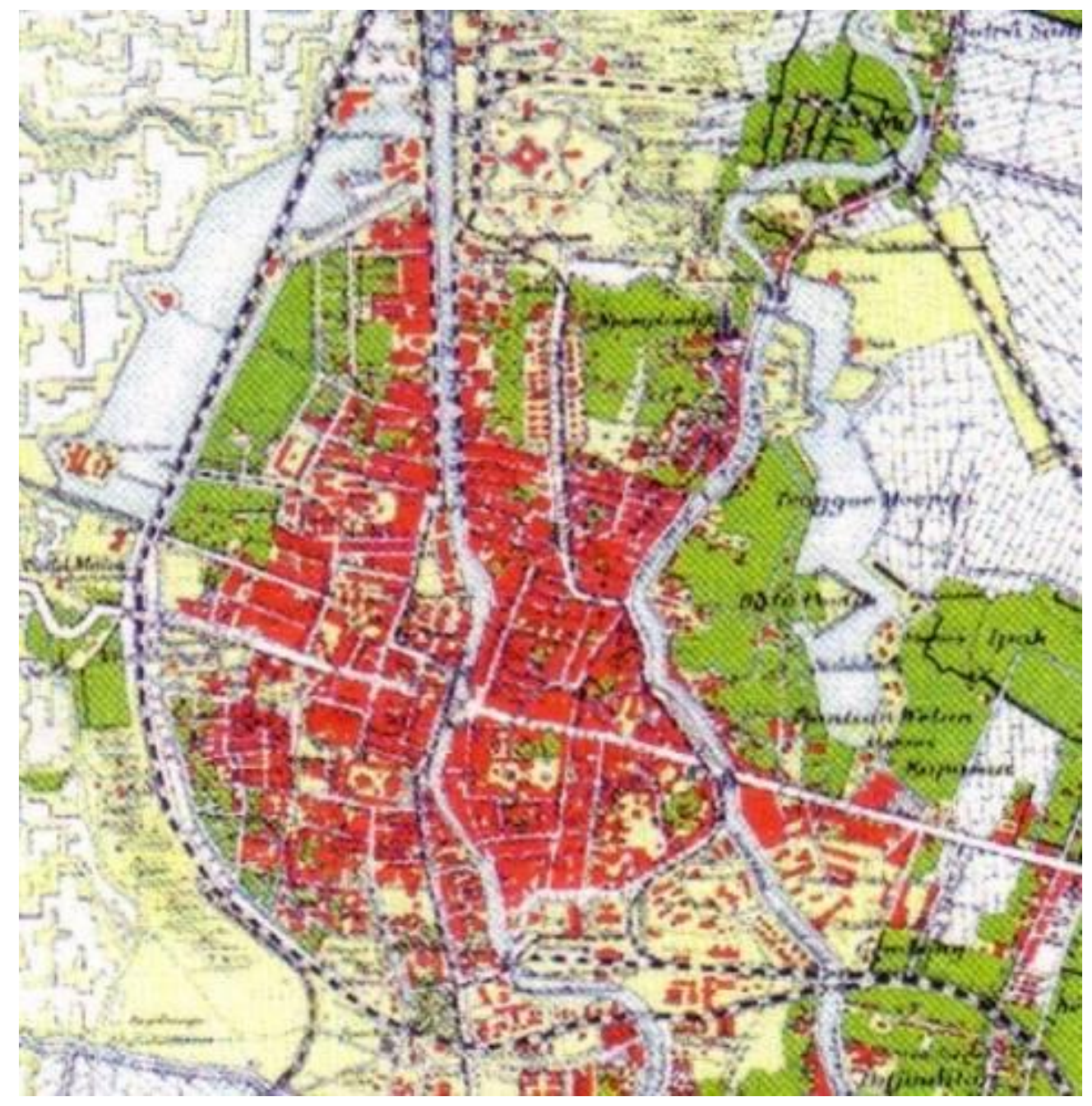

Gambar 2. Kota Surabaya tahun 1905

Melalui ketentuan Undang-undang Wilayah atau Wijkenstelsel pada tahun 1843, Kota Bawah (Beneden Stad) dibagi menjadi menjadi beberapa wilayah permukiman berdasarkan etnis yaitu permukiman orang Eropa berada di sisi Barat Jembatan Merah dan permukiman masyarakat Timur Asing (Vreande Oosterlingen) berada di sisi Timur yang terdiri dari permukiman Tionghoa (Chineesche Kamp), Arab (Arabische Kamp) dan permukiman masyarakat pribumi yang menyebar di sekitar hunian masyarakat Tionghoa dan Arab.

Penghancuran benteng kota pada tahun 1871 dan pada tahun 1910 UU Wilayah (Wijkenstelsel) sudah tidak diberlakukan menyebabkan semakin luasnya pengaruh masyarakat Tionghoa terhadap kegiatan perdagangan dan jasa, semakin luasnya pengaruh budaya Tionghoa yang ditandai dengan berdirinya kelenteng di luar kawasan asli Tionghoa (Kembang Jepun) sehingga menyebabkan hilangnya karakter Kembang Jepun sebagai pusat kebudayaan masyarakat Tionghoa di Kota Surabaya.

\section{Perkembangan Penggunaan Lahan}

Kawasan Kembang Jepun memiliki penggunaan lahan perdagangan dan jasa $(84,86 \%)$, perumahan $(14,71 \%)$, peribadatan berupa kelenteng $(0.29 \%)$ dan kantor $(0.14 \%)$. Pola ruang perdagangan dan jasa membentuk pola linier mengikuti jaringan jalan (jalan Karet, Jalan Gula, Jalan Coklat, Jalan Teh, jalan Slompretan, Jalan Bongkaran, Jalan Waspada, Jalan Kalimati Wetan dan Jalan Panggung) dan konsentrik (Jalan Kembang Jepun).

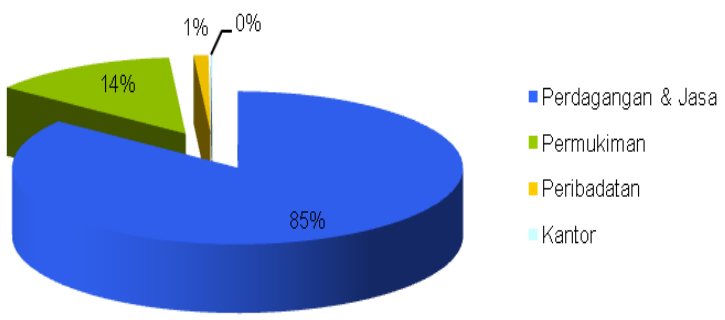

Gambar 3. Prosentase penggunaan lahan 


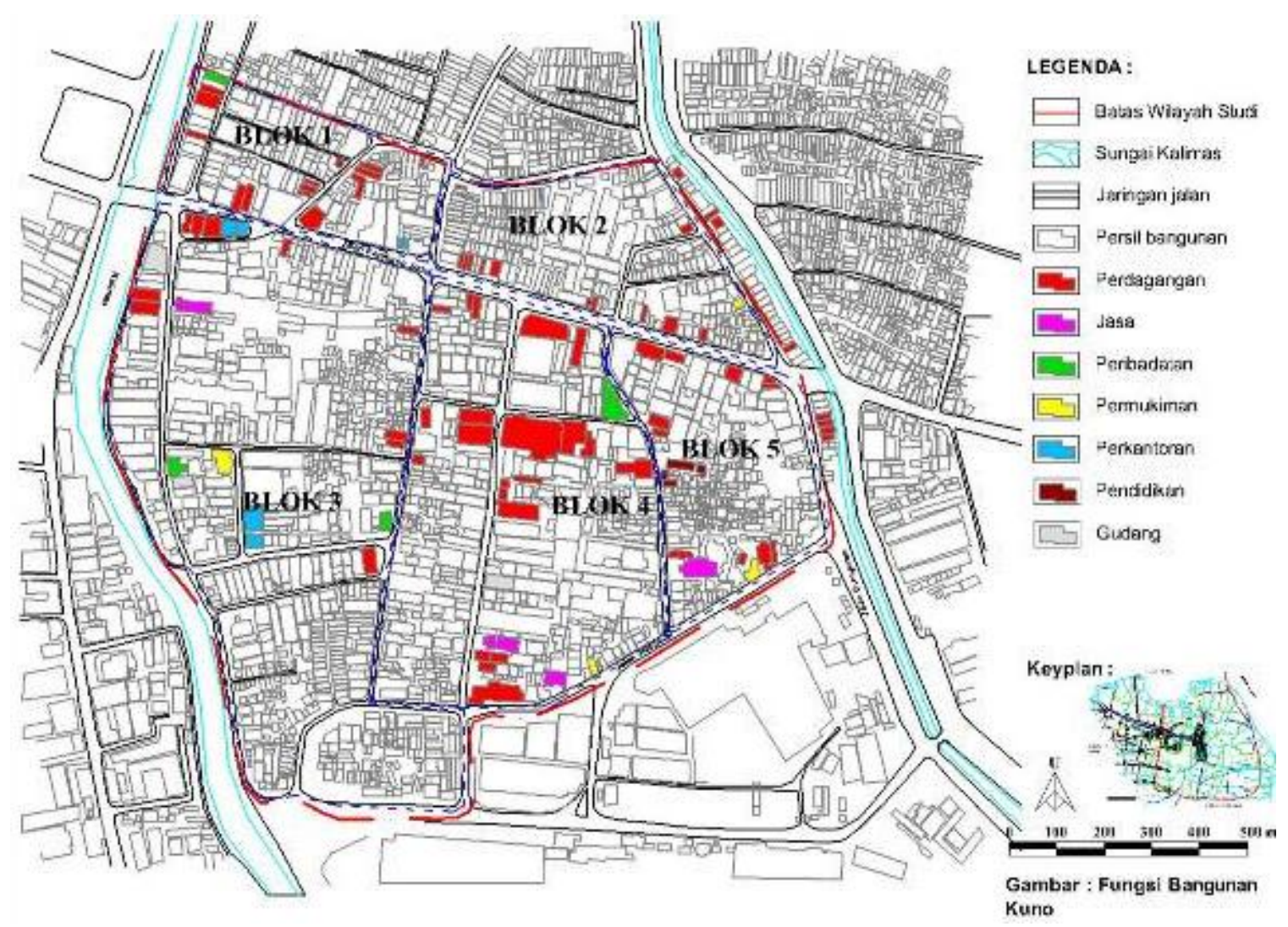

Gambar 4. Kondisi fungsi bangunan kuno di kawasan Kembang Jepun

\section{Kondisi Bentuk dan Tatanan Massa Bangunan}

Sebanyak 28\% bangunan kuno terdapat di koridor Jalan Kembang Jepun (24 bangunan) dan sebanyak 8 bangunan kuno terdapat di Jalan Kalimati Kulon dan sisanya tersebar di koridor Jalan Panggung, Jalan Dukuh, Jalan Songoyudan, Jalan Bibis, Jalan Karet, Jalan Cokelat, Jalan Teh, Jalan Gula, Jalan Slompretan, Jalan Kopi, Jalan Waspada, Jalan Samudra, Jalan Bongkaran dan Jalan Bunguran. Bangunan kuno di Kawasan Kembang Jepun memiliki fungsi perdagangan (67\%), jasa (8\%), perkantoran $(8 \%)$, rumah $(6 \%)$, gudang $(6 \%)$, peribadatan (4\%) dan pendidikan (1\%).

Sebanyak 19\% bangunan kuno sudah pernah mengalami perubahan fungsi, sedangkan $81 \%$ bangunan kuno masih mempertahankan fungsi asli (Gambar 6).

Sebesar $47 \%$ masyarakat sudah tinggal di Kawasan Kembang Jepun selama lebih dari 15 tahun, sedangkan $51 \%$ masyarakat di Kawasan Kembang Jepun mendapatkan bangunan yang ditempati sekarang dengan cara menyewa dan status bangunan kuno di Kawasan Kembang Jepun sebanyak 40\% adalah Hak Guna Bangunan.

Pemeliharaan yang dilakukan pada bangunan kuno umumnya adalah renovasi bagian dalam bangunan (46\%) dan kesulitan yang dialami pemilik dalam kegiatan pemeliharan bangunan kuno umumnya adalah karena tidak mengetahui teknis perawatan bangunan kuno (45\%).

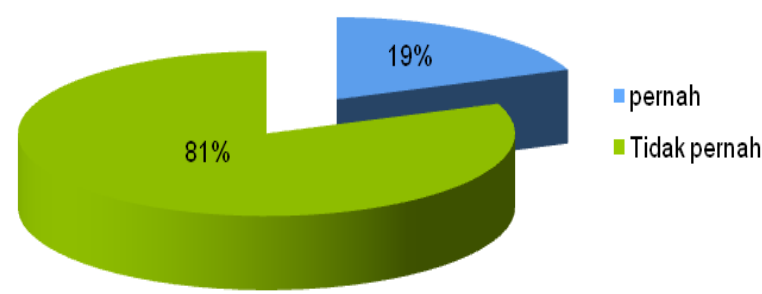

Gambar 5. Perubahan fungsi bangunan kuno

Tabel 1. Pemeliharan bangunan kuno

\begin{tabular}{|c|c|c|c|}
\hline No. & Pemeliharaan bangunan & Esampel & $\%$ \\
\hline \multicolumn{4}{|c|}{ Tindakan } \\
\hline 1 & Pengecatan secara berkala & 18 & 20 \\
\hline 2 & Perbaikan ornamen yang rusak & 11 & 12 \\
\hline 3 & Merombak bagian luar bangunan & 2 & 2 \\
\hline 4 & Merenovasi bagian dalam bangunan & 40 & 46 \\
\hline 5 & Tidak ada perawatan & 18 & 20 \\
\hline \multicolumn{4}{|c|}{ Kendala pemeliharaan } \\
\hline 1 & Biaya perawatan mahal & 7 & 8 \\
\hline 2 & Tidak mengetahui teknis perawatan & 40 & 45 \\
\hline 3 & Sulit mendapatkan ornamen asli & 22 & 25 \\
\hline 4 & Tidak ada bantuan pemerintah & 9 & 10 \\
\hline 5 & Tidak minat melakukan pemeliharaan & 11 & 12 \\
\hline
\end{tabular}

Sumber: Eka Sari, 2011 
Intensitas kepadatan bangunan di kawasan Kembang Jepun adalah 80-100\%, KLB 0,6-3,6 dan garis sempadan bangunan 0-20 meter.

\section{Kondisi Sosial Ekonomi}

97\% penduduk bekerja di sektor jasa/perdagangan, sedangkan $3 \%$ penduduk bekerja di sektor industri (Gambar 7).

Berdasarkan suku, masyarakat Tionghoa yang tinggal di kawasan Kembang Jepun mayoritas adalah suku Hok Kian/Hakka dengan mata pencaharian utama sebagai pedagang (Simatauw 2005: 31). Lebih jelas mengenai mata pencaharian Tionghoa di kawasan Kembang Jepun sebagia berikut (Tabel 2).

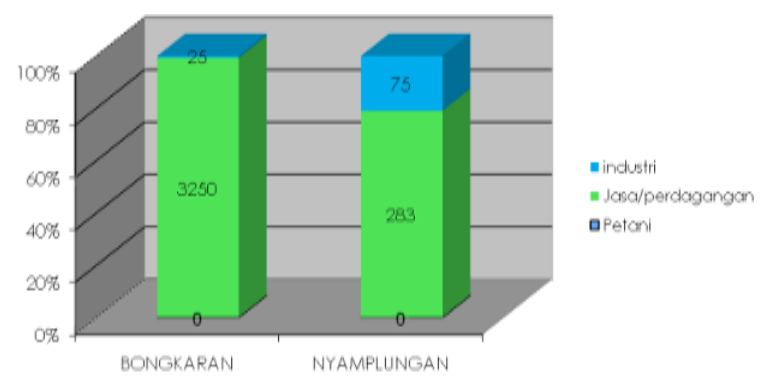

Gambar 6. Struktur mata pencaharian penduduk

Tabel 2. Ragam Suku dan Mata Pencaharian Etni Tionghoa di Kawasan Kembang Jepun

\begin{tabular}{|c|c|c|}
\hline Suku & Sub suku & Mata pencaharian \\
\hline Hok Kian/ & Tjwan Tjiu & Pedagang palawija \\
\hline \multirow[t]{7}{*}{ Hakka } & & Toko \\
\hline & Hok Jia & Pedagang kelontong \\
\hline & & Pedagang kain \\
\hline & & Pedagang besi \\
\hline & & Pedagang bahan bangunan \\
\hline & Hok Tjiu & $\begin{array}{l}\text { Pengrajin/pedagang barang-barang } \\
\text { dari emas }\end{array}$ \\
\hline & Sien Niu & $\begin{array}{l}\text { Persewaan/pengrajin/pedagang } \\
\text { sepeda }\end{array}$ \\
\hline KwangTung/ & Sin Hwe & Pengrajin/tukang kayu \\
\hline \multirow[t]{4}{*}{ Canton } & Thai San & Pengusaha restoran \\
\hline & & Tukang masak \\
\hline & & Penjahit \\
\hline & Gek Lang & Pedagang obat-obatam Cina \\
\hline Hu Pek & & Tukang gigi \\
\hline
\end{tabular}

Sumber: Simatauw (2005:32)

\section{Kondisi Sosial Budaya}

Orang-orang Tionghoa perantauan datang ke Surabaya pada waktu Surabaya masih berbentuk kerajaan, yaitu abad ke-14. Pada awalnya orang Tionghoa beraktifitas sebagai pedagang hasil bumi, terutama beras di kawasan Pasar Besar. Pada awal kedatangannya, orang-orang Tionghoa bermukim secara kelompok di sebelah Timur Kalimas yang dibatasi oleh Jalan Karet, Jalan Coklat, Jalan Slompretan dan Jalan Kembang Jepun. Perkembangan awal permukiman orang Tionghoa adalah kearah Utara memasuki kawasan Perkampungan Arab. Awalnya Hendelstraat (Jl. Kembang Jepun) adalah perbatasan antara kampung Pecinan dengan kampung Arab. Jalan Kalimati dan Jalan Songoyudan awalnya termasuk wilayah Kampung Arab, tetapi kemudian wilayah ini diberikan oleh orang-orang Arab sendiri ke orang-orang Tionghoa dengan tujuan mencari keuntungan dan meramaikan perdagangan orangorang Arab sendiri. Secara umum nuansa Pecinan yang ada di wilayah studi dapat dilihat dari keberadaan fasilitas yang berkaitan dengan masyarakat etnis Tionghoa, seperti (Elviana 2009:55):

- Tersedianya menu makanan khas Cina, seperti kue "Tiong Ciu Pia" yang dijual pada beberapa restoran atau toko-toko yang tersebar di dalam kawasan;

- Adanya toko-toko yang menjual khusus peralatan dan perlengkapan sembahyang, seperti hio, dupa, ilin serta hiasan-hiasan Cina lainnya, seperti lampion dan lain-lain;

- Adanya toko yang menjual seni batu pahat untuk makam, yaitu batu "bong pai";

- Masih terdapat sarana sebagai tempat pengobatan tradisional ala Cina seperti tusuk jarum/akupuntur; dan

- Adanya perkumpulan sosial, yang secara rutin menyelenggarakan berbagai acara pagelaran seni seperti barongsai.

\section{Kegiatan Masyarakat}

Kegiatan yang dilakukan masyarakat Kembang Jepun, terutama masyarakat etnis Tionghoa terdiri dari kegiatan ekonomi perdagangan, kegiatan keagamaan, kegiatan menjalankan tradisi/leluhur, kegiatan kemasyarakatan dan kegiatan seni budaya (Elviana 2009: 130-133).

A. Kegiatan ekonomi perdagangan

Kegiatan usaha perdagangan umumnya dilakukan secara turun temurun. Kegiatan untuk menjalankan usaha toko ini merupakan bagian dari rutinitas kegiatan sehari-hari, sehingga menjadikan aktifitas hunian menyatu dengan aktifitas ekonomi.

B. Kegiatan keagamaan

Kegiatan yang bersifat keagamaan seperti bersembahyang dan berdoa dilakukan di kelenteng, dapat dilakukan sewaktu-waktu sesuai dengan kebutuhan dan ada beberapa anggota masyarakat yang melakukan kegiatan keagamaan secara rutin. Kegiatan bersembahyang dilakukan secara pribadi dan berkelompok, dengan memanfaatkan kelen- 
teng Hok An Kiong di Jalan Coklat. Disamping kegiatan keagamaan Konghucu, juga ada kegiatan keagamaan umat Kristen di gereja Kristus Tuhan di Jalan Samudra (Gambar 10).
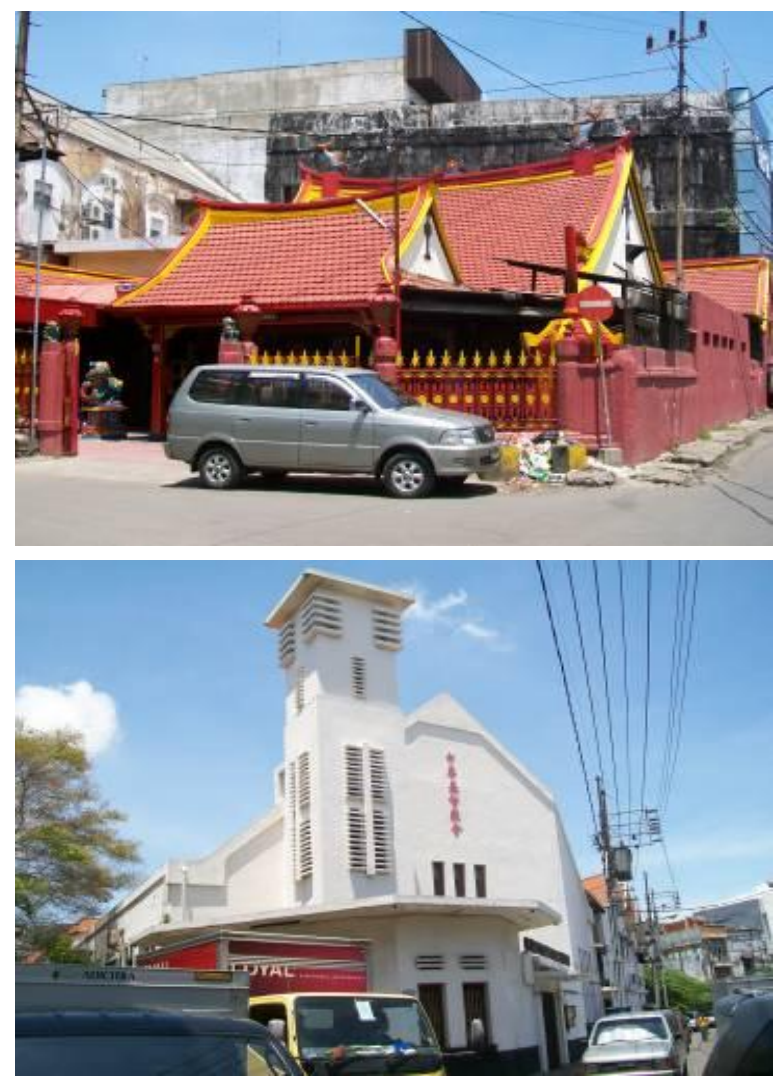

Gambar 8. Fasilitas untuk kegiatan keagamaan di Kembang Jepun

C. Kegiatan menjalankan tradisi/leluhur Kegatan yang bersifat menjalankan tradisi leluhur cukup bervariatif dan umumnya berhubungan dengan hari-hari besar keagamaan seperti:

- Kegiatan yang dilaksanakan pada perayaan Imlek antara lain bazar, pagelaran wayang "potehi".

- Perayaan Cap Gome, yaitu kegiatan saling mengunjungi sanak saudara dan diakhiri dengan berkumpul seluruh keluarga besar untuk makan bersama;

- Kegiatan Ceng Beng, yaitu ritual mengunjungi dan membersihkan makam leluhur serta mengirimkan doa yang dilakukan di rumah abu; dan

- Kegiatan pengobatan tradisional Tionghoa, yaitu akupuntur/tusuk jarum.

D. Kegiatan kemasyarakatan

Kegiatan kemasyarakatan di kawasan Kembang Jepun dilakukan melalui anggota perkumpulan. Kegiatan anggota perkumpulan ini disesuaikan dengan lingkungannya. Bagi masyarakat Tionghoa yang menjadi umat Kristiani, mereka tergabung dalam Perkumpulan Bakti Doa di Gereja Kristus Tuhan di Jalan Samudra. Umat Budha atau Konghucu tergabung dalam perkumpulan Meditasi Tri Dharma yang umumnya menyelenggarakan kegiatan di luar wilayah studi.

E. Kegiatan seni budaya

Kegiatan seni budaya yang dijalankan sebagian masyarakat Tionghoa terdiri dari seni bela diri (wushu) dan seni tari (Barongsai). Kegiatan ini bersifat massal/kelompok dengan anggota puluhan orang. Kegiatan pelatihannya dilakukan secara rutin yang bertempat di luar area kawasan studi. Pagelaran seni wushu dan barongsai umumnya dilakukan di kawasan studi pada saat even-even tertentu seperti hari raya Imlek

\section{Persepsi Masyarakat Terhadap Nilai Makna Kultural Bangunan Kuno}

Analisis terhadap persepsi masyarakat dilakukan terhadap pemilik atau pengguna 89 bangunan kuno yang tersebar di 5 blok penelitian di Kawasan Kembang Jepun. Pengumpulan data persepsi dilakukan dengan metode kuisioner yang dilakukan pada 12-17 Oktober 2010. Dasar pemilihan 5 blok penelitian sebagai berikut (gambar 9).

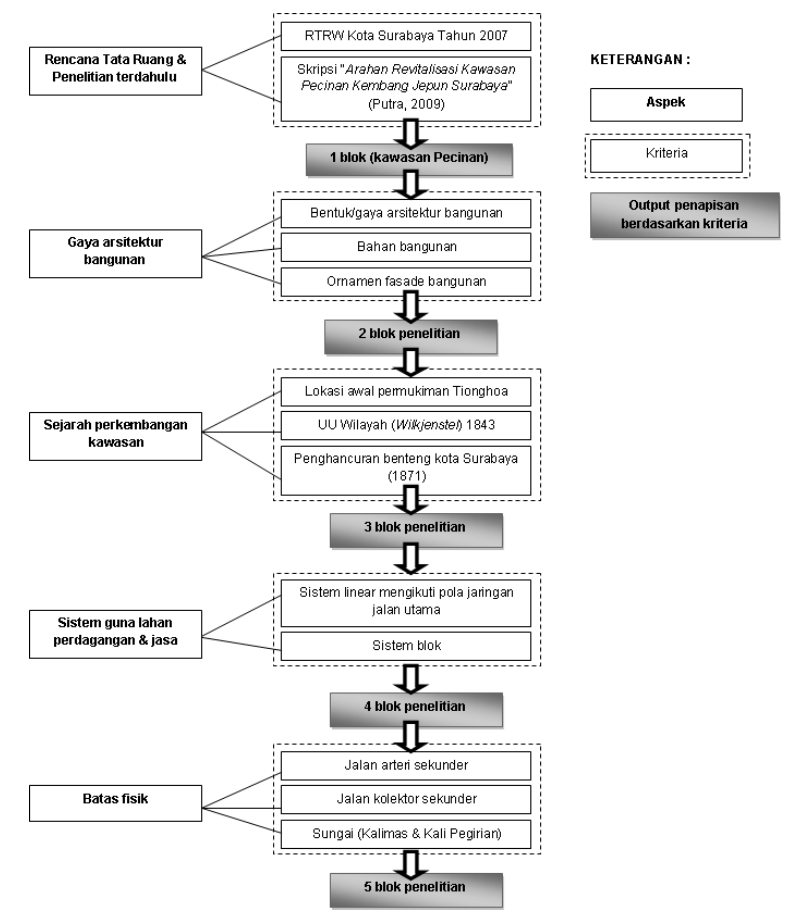

Gambar 9. Metode Pemilihan Blok Penelitian

Hasil pemilihan blok penelitia selanjutnya dibreakdown untuk mendapatkan 89 sampel bangun- 
an kuno yang didasarkan pada kriteria-kriteria berikut (Gambar 9):

- SK Walikota Surabaya nomor 188.45/004/402. 1.04/1998 mengenai penetapan lokasi benda dan situs cagar budaya yang harus dilindungi;

- Hasil penelitian Virgyani (2002) mengenai pelestarian di Kawasan Kembang Jepun;

- Bangunan yang berusia minimal 50 tahun atau dibangun pada periode tahun 1965 ke atas (terhitung mulai 2010), hal tersebut sesuai dengan ketentuan yang disebutkan di dalam Peraturan Daerah Nomor 5 Tahun 2005 Tentang Pelestarian
Bangunan Dan/Atau Lingkungan Cagar Budaya;

- Kesamaan jenis aktivitas kegiatan pada bangunan dan tapak, yaitu sebagai kawasan perdagangan dan jasa serta permukiman; dan diupayakan dapat mewakili kriteria-kriteria pelestarian di kawasan Pecinan Kembang Jepun.

Item-item yang dgunakan dalam analisis persepsi masyarakat adalah nilai-nilai makna kultural bangunan kuno antara lain Umur, Estetika, Kelangkaan, Keaslian, Memperkuat Kawasan dan Citra Kawasan (Tabel 3).

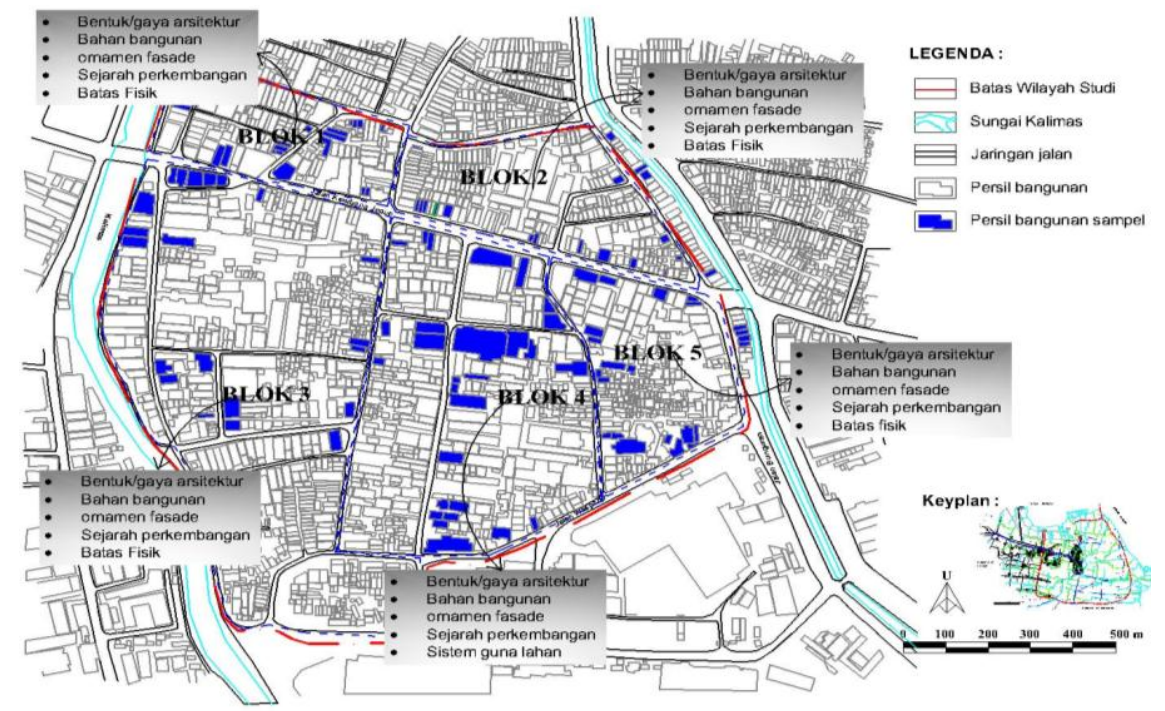

Gambar 7. Hasil Pemilihan Sampel Bangunan Kuno

Tabel 3. Item-item untuk Importance Performance Analysis

\begin{tabular}{|c|c|c|}
\hline $\begin{array}{l}\text { Sub variabel makna } \\
\text { kultural }\end{array}$ & Pertimbangan & kriteria penilaian \\
\hline Umur & $\begin{array}{l}\text { Berkenaan dengan batas usia bangunan - } \\
\text { cagar budaya sekurang-kurangnya } 50 \text { (lima } \\
\text { puluh) tahun }\end{array}$ & $\begin{array}{l}\text { - usia bangunan minimal } 50 \text { tahun (dibangun pada periode tahun } 1960 \\
\text { dan sebelumnya) }\end{array}$ \\
\hline \multirow[t]{3}{*}{ Estetika } & Gaya arsitektur bangunan & $\begin{array}{l}\text { - Bangunan memiliki gaya arsitektur kolonial Belanda (Indische } \\
\text { Empire Stijl, Modern 1900-an, Modern Romantik, Modern 1915-an, } \\
\text { Nieuwe Kunst) atau gaya arsitektur Cina (Ruma Toko) } \\
\text { - Memiliki ciri khas ornamen arsitektur kolonial pada fasade bangunan } \\
\text { kanopi/tritisan dan dormer) }\end{array}$ \\
\hline & Bahan/material bangunan & - Memiliki bahan/material bangunan yang tahan lama \\
\hline & Skala dan proporsi bangunan & - $\quad$ KDB, KLB, DAN GSmB sama dengan bangunan kuno sekitar \\
\hline Kelangkaan & $\begin{array}{l}\text { Kebijakan pemerinth } \\
\text { Usia bangunan }\end{array}$ & $\begin{array}{l}\text { - } \quad \text { Dikategorikan sebagai situs cagar budaya dalam SK Cagar Budaya } \\
\text { - } \quad \text { Mewakili gaya arsitektur kolonial Belanda dan Cina }\end{array}$ \\
\hline \multirow[t]{2}{*}{ Keaslian } & Bentuk fisik bangunan & $\begin{array}{l}\text { - Fisik bangunan yang menunjukkan karakter arsitektur kolonial } \\
\text { Belanda atau Cina tidak berubah }\end{array}$ \\
\hline & Facade bangunan & $\begin{array}{l}\text { - } \quad \text { Cat bangunan tidak berubah } \\
\text { - } \text { Bahan/material bangunan tidak berubah } \\
\text { - } \text { Bentuk muka bangunan tidak berubah }\end{array}$ \\
\hline Memperkuat kawasan & $\begin{array}{l}\text { Bentuk dan ukuran bangunan } \\
\text { Fungsi bangunan }\end{array}$ & $\begin{array}{ll}\text { - } & \text { Berukuran monumental } \\
\text { - } & \text { Fungsi bangunan dipertahankan sesuai fungsi aslinya }\end{array}$ \\
\hline \multirow[t]{2}{*}{ Citra kawasan } & $\begin{array}{l}\text { Pengulangan ciri bangunan } \\
\text { Makna bangunan }\end{array}$ & $\begin{array}{l}\text { - } \quad \text { Ciri bangunan diulang secara dominan pada bangunan lain } \\
\text { - } \quad \text { Merupakan tengeran kawasan } \\
\text { - } \quad \text { Mewakili perkembangan arsitektur Kolonial di Kota Surabaya }\end{array}$ \\
\hline & Fungsi bangunan & $\begin{array}{l}\text { - Fungsi bangunan sesuai dengan ciri khas Kawasan Kembang Jepun } \\
\text { (perdagangan skala kecil dan rumah) }\end{array}$ \\
\hline
\end{tabular}


Berdasarkan hasil perhitungan dengan metode Importance Performance Analysis dapat diketahui bahwa prioritas bobot makna kultural untuk bangunan kuno di Kawasan Kembang Jepun terdiri : a) Prioritas sangat penting (bobot 3) adalah item-item makna kultural yang terdapat pada kuadran 4 pada Diagram Cartesius IPA; b) Prioritas penting (bobot 2) adalah item-item makna kultural yang terdapat pada kuadran 1 pada diagram Cartesius IPA; dan c) Prioritas tidak penting (bobot 1) adalah item-item makna kultural yang terdapat pada kuadran 3 pada diagram Cartesius IPA (Gambar 11).

Lebih jelas mengenai bobot masing-masing item makna kultural di kawasan Kembang Jepun (Tabel 4).

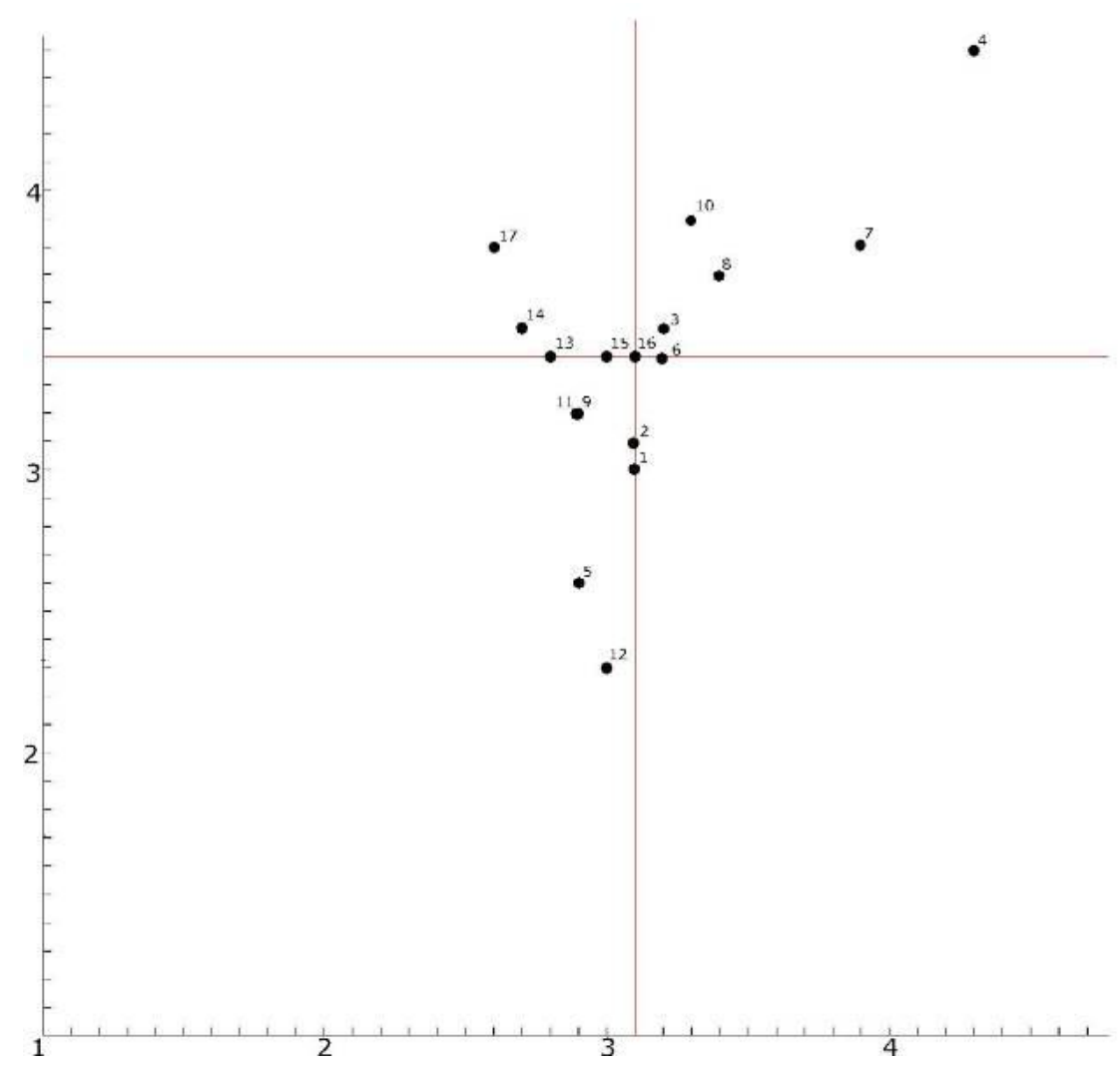

Gambar 8. Diagram Cartesius Persepsi Preferensi Masyarakat Kembang Jepun

Tabel 4. Bobot Item Makna Kultural Bangunan Kuno di Kawasan Kembang Jepun

\begin{tabular}{|c|c|c|c|}
\hline Makna kultural & Kode & Item & Bobot \\
\hline $\operatorname{Umur}(\mathrm{A})$ & 1 & Bangunan berusia minimal 50 tahun & 1 \\
\hline \multirow[t]{4}{*}{ Estetika (B) } & 2 & Bangunan memiliki gaya arsitektur Kolonial/Cina & 1 \\
\hline & 3 & Memiliki cirri khas ornamen arsitektur kolonial/Cina pada fasade & 2 \\
\hline & 4 & Bahan/material tahan lama & 2 \\
\hline & 5 & KDB, KLB, DAN GSmB sama dengan bangunan kuno sekitar & 1 \\
\hline \multirow[t]{2}{*}{ Kelangkaan (C) } & 6 & Dikategorikan sebagai situs cagar budaya dalam SK Cagar Budaya & 2 \\
\hline & 7 & Mewakili gaya arsitektur kolonial Kolonial/Cina & 2 \\
\hline \multirow[t]{4}{*}{ Keaslian (D) } & 8 & Fisk bangunan yang menunjukkan karakter arsitektur Kolonial atau Cina tidak berubah & 2 \\
\hline & 9 & Cat bangunan tidak berubah & 1 \\
\hline & 10 & Bahan/material bangunan tidak berubah & 2 \\
\hline & 11 & Bentuk muka bangunan tidak berubah & 1 \\
\hline \multirow[t]{2}{*}{ Memperkuat kawasan (E) } & 12 & Berukuran monumental & 1 \\
\hline & 13 & Fungsi asli bangunan dipertahankan & 3 \\
\hline \multirow[t]{4}{*}{ Citra kawasan $(\mathrm{F})$} & 14 & Cirri bangunan diulang secara dominan pada bangunan lain & 3 \\
\hline & 15 & Merupakan tengeran kawasan & 3 \\
\hline & 16 & Mewakili perkembangan arsitektur Kota Surabaya & 2 \\
\hline & 17 & Fungsi bangunan sesuai dengan karakter kawasan & 3 \\
\hline
\end{tabular}

Sumber: Eka Sari, 2011 
Setelah diketahui bobot masing-masing item makna kultural, selanjutnya untuk mengetahui nilai makna kultural masing bangunan kuno maka dilakukan pembobotan dengan menggabungkan bobot item makna kultural berdasarkan analisis IPA dengan nilai masing-masing bangunan kuno berdasarkan hasil observasi lapangan. Item-item yang dinilai dalam mengobservasi nilai bangunan menggunakan itemitem makna kultural. Sebagai contoh berikut (Tabel 5) adalah nilai bangunan kuno di Jalan Kembang Jepun no. 138 (KJ 138) berdasarkan observasi lapangan.
Observasi lapangan yang sama dilakukan pada semua sampel bangunan kuno (89 sampel bangunan kuno) di 5 blok penelitian Kawasan Pecinan Kembang Jepun. Hasil dari analisis IPA (Bobot makna kultural) dengan hasil dari observasi lapangan (nilai observasi bangunan kuno) kemudian digabungkan untuk mendapatkan nilai total makna kultural bangunan kuno. Berikut adalah salah satu contoh perhitungan nilai total makna kultural bangunan kuno KJ 138 (Tabel 6)

Tabel 5. Nilai Bangunan KJ 138 Berdasarkan Observasi Lapangan

\begin{tabular}{|c|c|c|c|c|}
\hline \multirow{2}{*}{$\begin{array}{l}\text { Kode bangunan } \\
\text { KJ } 138\end{array}$} & \multicolumn{2}{|c|}{ Makna kultural } & Nilai & Hasil observasi lapangan \\
\hline & Umur & A1 & 2 & Didirikan pada tahun 1942 (berusia 69 tahun) \\
\hline & Estetika & B2 & 2 & Memiliki gaya arsitektur Kolonial Nieuwe Bouwen \\
\hline & & B3 & 2 & atap datar dari beton, fasade simetris, ornamentasi berbentuk geometris \\
\hline & & B4 & 2 & $\begin{array}{l}\text { Bahan bangunan pada fasade masih bertahan walaupun dalam kondisi tidak } \\
\text { terawatt dan kotor }\end{array}$ \\
\hline & & B5 & 2 & Bangunan memiliki KDB 100\% dan 2 lantai, sama dengan bangunan sekitarmya \\
\hline & Kelangkaan & C6 & 1 & $\begin{array}{l}\text { Belum ditetapkan sebagai benda cagar budaya dalam SK Cagar Budaya Kota } \\
\text { Surabaya }\end{array}$ \\
\hline & & $\mathrm{C} 7$ & 2 & $\begin{array}{l}\text { Gaya arsitektur Nieuwe Bouwen mewakili perkembangan arsitektur Kolonial } \\
\text { Belanda abad ke-19 }\end{array}$ \\
\hline & Keaslian & D8 & 2 & Tidak terjadi perubahan pada fasade bangunan \\
\hline & & D9 & 2 & Cat bangunan tidak mengalami perubahan dan tidak terawat \\
\hline & & $\mathrm{D} 10$ & 2 & Tidak terjadiperubahan pada material/bahan bangunan \\
\hline & & D11 & 2 & Tidak terjadi perubahan pada facade bangunan \\
\hline & $\begin{array}{l}\text { Memperkuat } \\
\text { kawasan }\end{array}$ & E12 & 1 & Bangunan tidak memiliki ukuran yang monumental \\
\hline & & E13 & 2 & Fungsi asli bangunan sebagai toko masih bertahan \\
\hline & Citra kawasan & F14 & 2 & Ciri simetris ornamen bangunan banyak diulang pada bangunan sekitarnya \\
\hline & & F15 & 1 & Bukan merupakan tengeran kawasan \\
\hline & & F16 & 1 & $\begin{array}{l}\text { Kondisi yang tidak terawat belum dapat mengurangi nilai bangunan dalam } \\
\text { perkembangan arsitektur }\end{array}$ \\
\hline & & F17 & 2 & Fungsi sebagai sarana perdagangan sesuai dengan karakter Pecinan \\
\hline
\end{tabular}

Sumber: Eka Sari, 2011

Tabel 6. Nilai Makna Kultural Bangunan Kuno KJ 138

\begin{tabular}{ccccc}
\hline Kode bangunan & kode makna kultural & Nilai bangunan & Bobot makna kultural & Nilai makna kutural bangunan \\
\hline KJ 138 & A1 & 2 & 1 & 2 \\
B2 & 2 & 1 & 2 \\
B3 & 2 & 2 & 4 \\
B4 & 2 & 2 & 4 \\
B5 & 2 & 1 & 2 \\
C6 & 1 & 2 & 2 \\
C7 & 2 & 2 & 4 \\
D8 & 2 & 2 & 2 \\
D9 & 2 & 1 & 4 \\
D10 & 2 & 2 & 2 \\
D11 & 2 & 1 & 1 \\
E12 & 1 & 1 & 6 \\
E13 & 2 & 3 & 6 \\
F14 & 2 & 3 & 3 \\
F15 & 1 & 2 & 2 \\
F16 & 1 & 3 & 6 \\
\hline
\end{tabular}


Berdasarkan perhitungan tersebut dapat diketahu nilai total makna kultural banguna kuno KJ 138 adalah 56. Metode perhitungan yang sama juga dilakukan pada semua sampel bangunan kuno (89 sampel) yang tersebar pada 5 blok penelitian di kawasan Pecinan Kembang Jepun dan didapatkan nilai total makna kultural bangunan di Kawasan Pecinan Kembang Jepun sebagai berikut.

\section{Strategi Pelestarian Bangunan Kuno}

Setelah dilakukan analisis terhadap nilai makna kultural bangunan kuno, langkah selanjutnya dalam menentukan strategi pelestarian bangunan kuno adalah penggolongan bangunan kuno menjadi 4 (empat) tingkatan pelestarian berdasarkan perda nomor 5 tahun 2005 tentang Benda Cagar Budaya Kota Surabaya pasa 11, yaitu:

- Bangunan golongan A: tingkat pelestarian tinggi (Preservasi);
- Bangunan golongan B: tingkat pelestarian cukup tinggi (Konservasi);

- Bangunan golongan C: tingkat pelestarian sedang (Revitalisasi); dan

- Bangunan golongan D: tingkat pelestarian rendah (Rehabilitasi).

Langkah penggolongan bangunan kuno menggunakan metode Sturgess dengan rumus:

$\mathrm{I}=\frac{\text { jarak (nilai maksimum }- \text { nilai minimum) }}{\text { jumlah kelas interval }}$

$\mathrm{I}=\frac{64-41}{4}$

$\mathrm{I}=5,75$

Keterangan:

$\mathrm{I}=$ kelas interval

Nilai maksimum dan nilai minimum dalam dilihat pada Tabel 7

Tabel 7. Nilai Makna Kultural Bangunan Kuno di Kawasan Pecinan Kembang Jepun

\begin{tabular}{|c|c|c|c|c|c|}
\hline Kode bangunan & Nilai makna kultural & Kode bangunan & Nilai makna kultural & Kode bangunan & Nilai makna kultural \\
\hline Blok penelitian I & Blok penelitian III & KJ 95 & 55 & & \\
\hline KJ 138 & 56 & Bibis 60 & 60 & KJ 137 & 50 \\
\hline KJ 164 & 48 & The 2 & 41 & Blok penelitian $\mathbf{V}$ & \\
\hline KJ 182 & 56 & The 17 & 43 & S 16 & 56 \\
\hline KJ 184 & 42 & K 46 & 57 & S 18 & 55 \\
\hline KK 4 & 53 & K 50 & 60 & S 41 & 50 \\
\hline KK 8 & 58 & K 68 & 58 & S 43 & 50 \\
\hline KK 10 & 58 & К 69 & 57 & $\mathrm{~S} 48$ & 52 \\
\hline KK 11 & 46 & K 77 & 58 & W 4 & 45 \\
\hline KK 12 & 51 & K 85 & 58 & W 6 & 49 \\
\hline KK 21 & 50 & K 88 & 49 & W 10 & 54 \\
\hline KK 35 & 56 & G 4 & 59 & W 12 & 45 \\
\hline KK 38 & 49 & G 6 & 59 & B 310 & 54 \\
\hline PG 5 & 51 & SL 55 & 42 & B 312 & 52 \\
\hline PG 11 & 44 & SL 59 & 45 & B 314 & 58 \\
\hline PG 17 & 49 & SL 99 & 54 & В 316 & 56 \\
\hline PG 19 & 49 & KJ 151 & 64 & KJ 1 & 45 \\
\hline PG 28 & 53 & KJ 163 & 61 & KJ 7 & 54 \\
\hline PG 59 & 51 & KJ 165 & 61 & KJ 27 & 61 \\
\hline Blok penelitian II & Kelenteng & 63 & KJ 29 & 49 & \\
\hline D 3 & 56 & Blok penelitian IV & & & \\
\hline D 5 & 49 & K 9-15 & 52 & & \\
\hline D 14 & 53 & K 10 & 53 & & \\
\hline D 32 & 55 & K 19 & 53 & & \\
\hline D 33 & 44 & K 21 & 48 & & \\
\hline D 68 & 48 & W 46 & 54 & & \\
\hline KJ 8 & 55 & W 58 & 59 & & \\
\hline KJ 18 & 45 & W 68 & 56 & & \\
\hline KJ 20 & 53 & SL 80 & 48 & & \\
\hline KJ 22 & 53 & SL 90 & 50 & & \\
\hline KJ 34 & 58 & S 39 & 58 & & \\
\hline KJ 62 & 42 & S 51 & 63 & & \\
\hline KJ 104-106 & 45 & B 4 & 46 & & \\
\hline KJ 108 & 45 & B 6 & 52 & & \\
\hline KJ 114 & 45 & B 14 & 50 & & \\
\hline KJ 118 & 58 & B 44 & 47 & & \\
\hline S 38 & 52 & KJ 89 & 47 & & \\
\hline
\end{tabular}


Tabel 8. Strategi Pelestarian Bangunan Kuno di Kawasan Pecinan Kembang Jepun

\begin{tabular}{ccccc}
\hline No. Kelas & Nilai makna kultural & Golongan & Jumlah bangunan kuno & Strategi pelestarian \\
\hline 1 & $61-68$ & A & 11 & Preservasi \\
2 & $55-61$ & B & 34 & Konservasi \\
3 & $48-54$ & C & 27 & Revitalisasi \\
4 & $41-47$ & D & 17 & Rehabilitasi \\
\hline
\end{tabular}

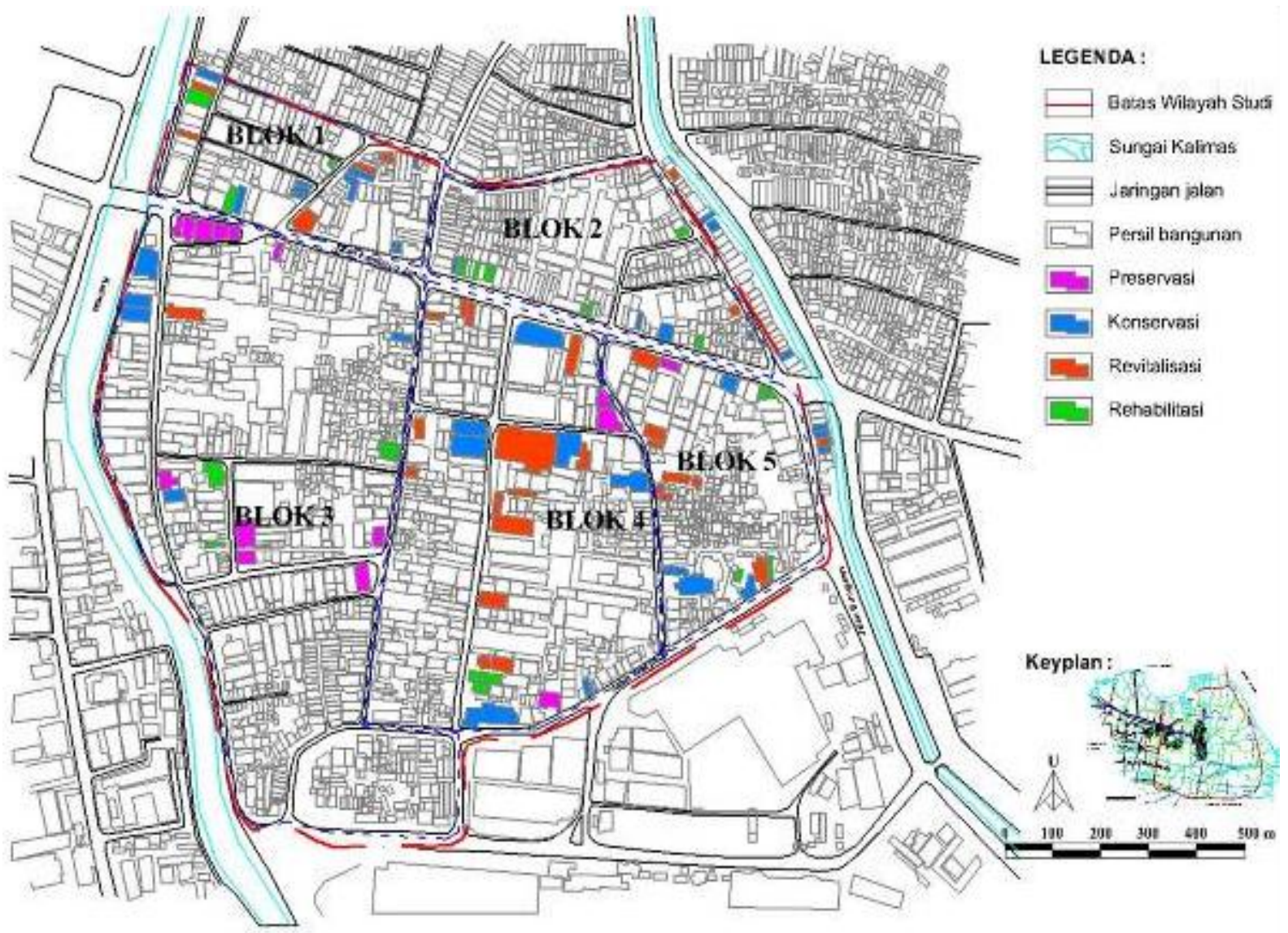

Gambar 9. Strategi pelestarian bangunan kuno

Berdasarkan hasil penggolongan bangunan kuno, dapat diklasifikasi strategi pelestarian bangunan kuno di kawasan Pecinan Kembang Jepun sebagai berikut (Tabel 8 dan Gambar 11) .

\section{KESIMPULAN}

\section{Persepsi Masyarakat Kawasan Pecinan Kembang Jepun}

Berdasarkan persepsi dan preferensi masyarakat terhadap nilai makna kultural bangunan, maka dapat diketahui bobot masing-masing item makna kultural berdasarkan prioritasnya adalah:

- Prioritas tinggi (bobot 3), yaitu makna kultural Memperkuat Kawasan (Fungsi asli bangunan dipertahankan) dan Citra Kawasan (Ciri bangunan diulang secara dominan pada bangunan lain, merupakan tengeran kawasan dan Fungsi bangunan sesuai dengan karakter kawasan);

- Prioritas sedang (bobot 2), yaitu Estetika (Memiliki ciri khas ornamen arsitektur Kolonial/Cina pada fasade, bahan/Material tahan lama), Kelangkaan (Dikategorikan sebagai cagar budaya dalam SK Walikota dan Memiliki gaya arsitektur kolonial/ Cina), Keaslian (Fisik bangunan kuno tidak berubah dan Bahan/material bangunan tidak berubah) dan Citra Kawasan (Mewakili perkembangan arsitektur Kota Surabaya)

- Prioritas rendah (bobot 1), yaitu Umur (Berusia minimal 50 tahun), Estetika (Memiliki gaya arsitektur bangunan Kolonial/Cina dan Memiliki $\mathrm{KDB}$, KLB dan GSmB homogen), Keaslian (Cat bangunan tidak berubah dan Bentuk fasade tidak berubah) dan Memperkuat Kawasan (Berukuran monumental). 


\section{Strategi Pelestarian Bangunan Kuno di Kawasan Pecinan Kembang Jepun}

Berdasarkan evaluasi terhadap bobot dan nilai makna kultural bangunan kuno serta penggolongan bangunan kuno, diketahui strategi pelestarian bangunan kuno di kawasan Pecinan Kembang Jepun adalah:

- Bangunan kuno golongan A dengan tingkat pelestarian tinggi dan strategi preservasi. Terdapat 11 bangunan kuno yang diarahkan untuk strategi pelestarian preservasi;

- Bangunan kuno golongan B dengan tingkat pelestarian cukup tinggi dan strategi pelestarian konservasi. Terdapat 34 bangunan kuno di kawasan Kembang Jepun yang diarahkan untuk strategi pelestarian konservasi;

- Bangunan kuno golongan C dengan tingkat pelestarian sedang dan strategi pelestarian revitalisasi. Terdapat 27 bangunan kuno di kawasan Kembang Jepun yang diarahkan untuk strategi pelestarian revitalisasi; dan

- Bangunan kuno golongan D dengan tingkat pelestarian rendah dan strategi pelestarian rehabilitasi. Terdapat 17 bangunan kuno di kawasan Kembang Jepun yang diarahkan untuk strategi pelestarian rehabilitasi.

\section{Ucapan Terimakasih}

Terimakasih kami ucapkan kepada Ketua Jurusan Arsitektur, Fakultas Teknik Sipil dan Perencanaan, UK Petra, Agus Dwi Hariyanto ST., MSc.; Tim Pengarah: Ir. Joyce M.Laurens, M.Arch., IAI; Timoticin Kwanda, B.Sc., MRP., Ph.D. (Cand.);
Ir. Danny S. Mintorogo, M.Arch.; Ir. Bisatya W. Maer, M.T.; Rony Gunawan Sunaryo, ST., MT. , Altrerosje Asri, ST., MT., Anik Juniwati, ST., MT. dan Para Reviewer Jurnal Dimensi.

\section{DAFTAR PUSTAKA}

Eka Sari, Kartika. (2011). Pelestarian Kawasan Kembang Jepun Kota Surabaya, Malang: Tesis tidak diterbitkan.

Handinoto. (1996). Perkembangan Kota dan Arsitektur Kolonial Belanda di Surabaya 18701940, Yogyakarta: Penerbit ANDI Yogyakarta.

Handinoto. (1999). "Lingkungan Pecinan Dalam Tata Ruang Kota di Jawa Pada Masa Kolonial", Dimensi, Juli, 20-29.

Kwanda, Timoticin. (2004). "Potensi dan Masalah Kota Bawah Surabaya Sebagai Kawasan Pusaka Budaya", Makalah disampaikan pada The 1st International Urban Conference, Surabaya: tanggal 23-25 Agustus 2004.

Putra, Radhitya Trsitya. (2009). Arahan Revitalisasi Kawasan Pecinan Kembang Jepun Surabaya. Skripsi Tidak Diterbitkan. Surabaya: ITS.

Poerbantanoe, Benny. "Partisipasi Masyarakat Didalam Pelestarian Dan Pendokumentasian Warisan (Arsitektur) Kota Surabaya Tahun 1706-1940": Universitas Kristen Petra Surabaya, http://puslit. petra.ac.id/journals/architecture/

Pemerintah Kota Surabaya. Peraturan Daerah Nomor 5 Tahun 2005 Tentang Pelestarian Bangunan dan/atau Lingkungan Cagar Budaya. Surabaya: Badan Perencanaan Pembangunan Kota Surabaya. 